\title{
Peatland records of solar activity
}

Bas van Geel ${ }^{1}$ and Dmitri Mauquoy ${ }^{2}$

IInstitute for Biodiversity and Ecosystem Dynamics, University of Amsterdam, The Netherlands; B.vanGeel@uva.nl

${ }^{2} \mathrm{~S}$ chool of Geosciences, University of Aberdeen, UK

\section{Rainwater-fed Holocene raised bog deposits in temperate climate zones are valuable archives of solar activity fluctuations and related climate changes.}

Past hydrological changes can be derived from the species composition and the degree of decomposition of peat-forming plants in raised bog deposits. More than 120 years ago Axel Blytt described transitions in raised bog deposits between dark, highly decomposed peat and light colored peat as evidence for climate change. Nowadays, the radiocarbon $\left({ }^{14} \mathrm{C}\right)$ method is generally used for dating Holocene climate-induced shifts in raised bog deposits. Yet radiocarbon offers more than the possibility to precisely date organic material. The changing atmospheric radiocarbon levels in the past are also a proxy for solar activity. We have found strong links between large ${ }^{14} \mathrm{C}$ fluctuations and major climate shifts.

\section{${ }^{14} \mathrm{C}$ wiggle-match dating and the \\ Sun}

The radioactive carbon isotope ${ }^{14} \mathrm{C}$ is produced under the influence of cosmic rays. When formed, the cosmogenic isotope radiocarbon is oxidized to ${ }^{14} \mathrm{CO}_{2}$, which becomes part of the carbon cycle. When plants and animals die, the uptake of carbon ceases and the decay of radiocarbon (half-life $5730 \pm 40$ years) to deduce age. Radiocarbon "years" are different from calendar years because the production of ${ }^{14} \mathrm{C}$ in the past was not constant, mainly due to changes in solar activity and related cosmic ray intensity. The ${ }^{14} \mathrm{C}$ timescale is calibrated by measuring the ${ }^{14} \mathrm{C}$ content of tree rings, dated precisely by means of dendrochronology. Changes in solar activity underlie fluctuations ("wiggles") in

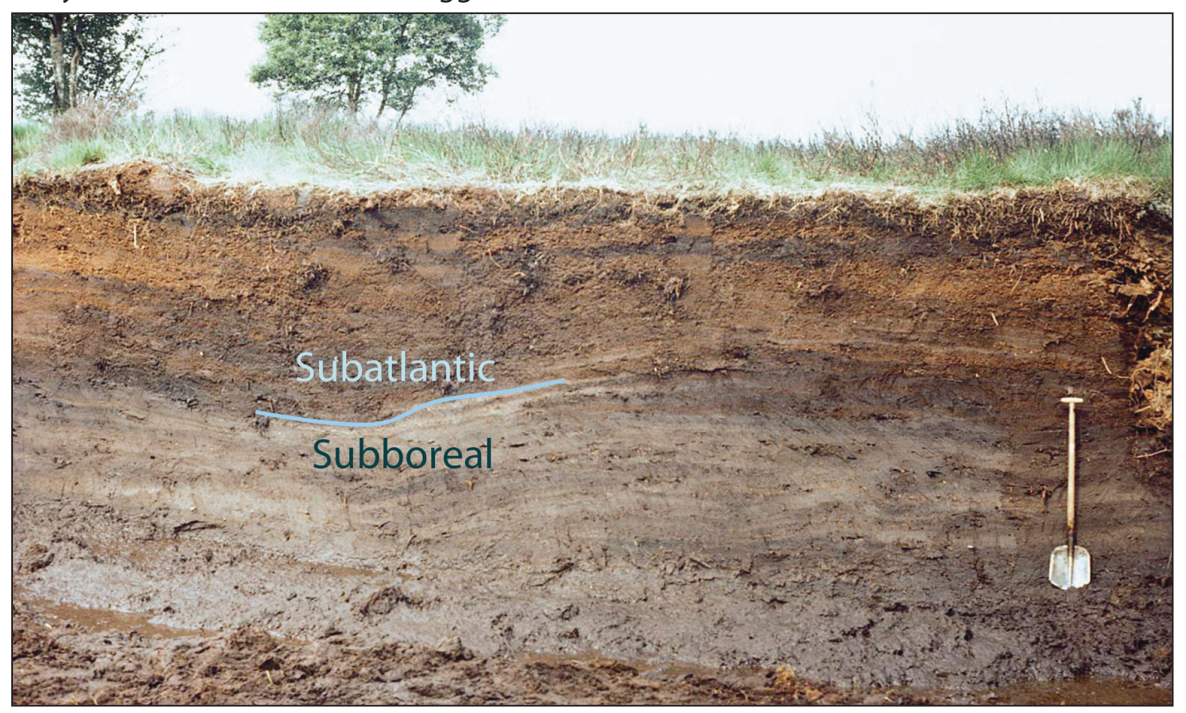

Figure 1: The Subboreal-Subatlantic transtion in a raised peat profile in The Netherlands. the ${ }^{14} \mathrm{C}$ calibration curve. Calibration of a single radiocarbon date usually yields an irregular probability distribution in calendar age, quite often over a long time interval. This is problematic in paleoclimatological studies, especially when a precise temporal comparison between different climate proxies is required. However, closely spaced sequences of (uncalibrated) ${ }^{14} \mathrm{C}$ dates of peat deposits also display the wiggles, which can be fitted to the wiggles in the radiocarbon calibration curve.

The practice of dating peat samples using ${ }^{14} \mathrm{C}$ "wiggle-match dating" has greatly improved the precision of radiocarbon chronologies (van Geel and Mook, 1989; Kilian et al., 1995; Blaauw et al., 2003). By wiggle-matching ${ }^{14} \mathrm{C}$ measurements, high-precision calendar-age chronologies for peat sequences can be generated, and several studies indicate that peatland surface wetness often increased together with rapid increases in atmospheric production of ${ }^{14} \mathrm{C}$ during the early Holocene, the Subboreal-Subatlantic transition (at ca. 2.8 cal ka BP; Fig. 1 and 2), and the Little Ice Age. Peat records from The Netherlands, the Czech Republic, the UK and Denmark show this phenomenon (Mauquoy et al., 2002a, b; Speranza et al., 2002; van der Plicht et al., 2004; van Geel et al., 1996, 1998). Because the production of radiocarbon is regulated by solar activity, periods of increased peatland surface wetness have been interpreted as evidence for solar forcing of climate change climatic shift towards increased humidity (equatorward relocation of mid-latitude storm tracks). The hypothesis is supported by palynological evidence. Areas that were initially hostile semi-deserts were converted into steppe landscapes with a high biomass production and carrying capacity. Newly available steppe areas could be utilized by herbivores, making them attractive for nomadic tribes. The equestrian Scythian culture expanded from Central Asia, and increased population density was a stimulus for westward migration towards south-eastern Europe.

Evidence for changes in peatland surface wetness, which coincide with grand solar minima during the Little Ice Age (Wolf, Spörer, Maunder and Dalton Mini- 


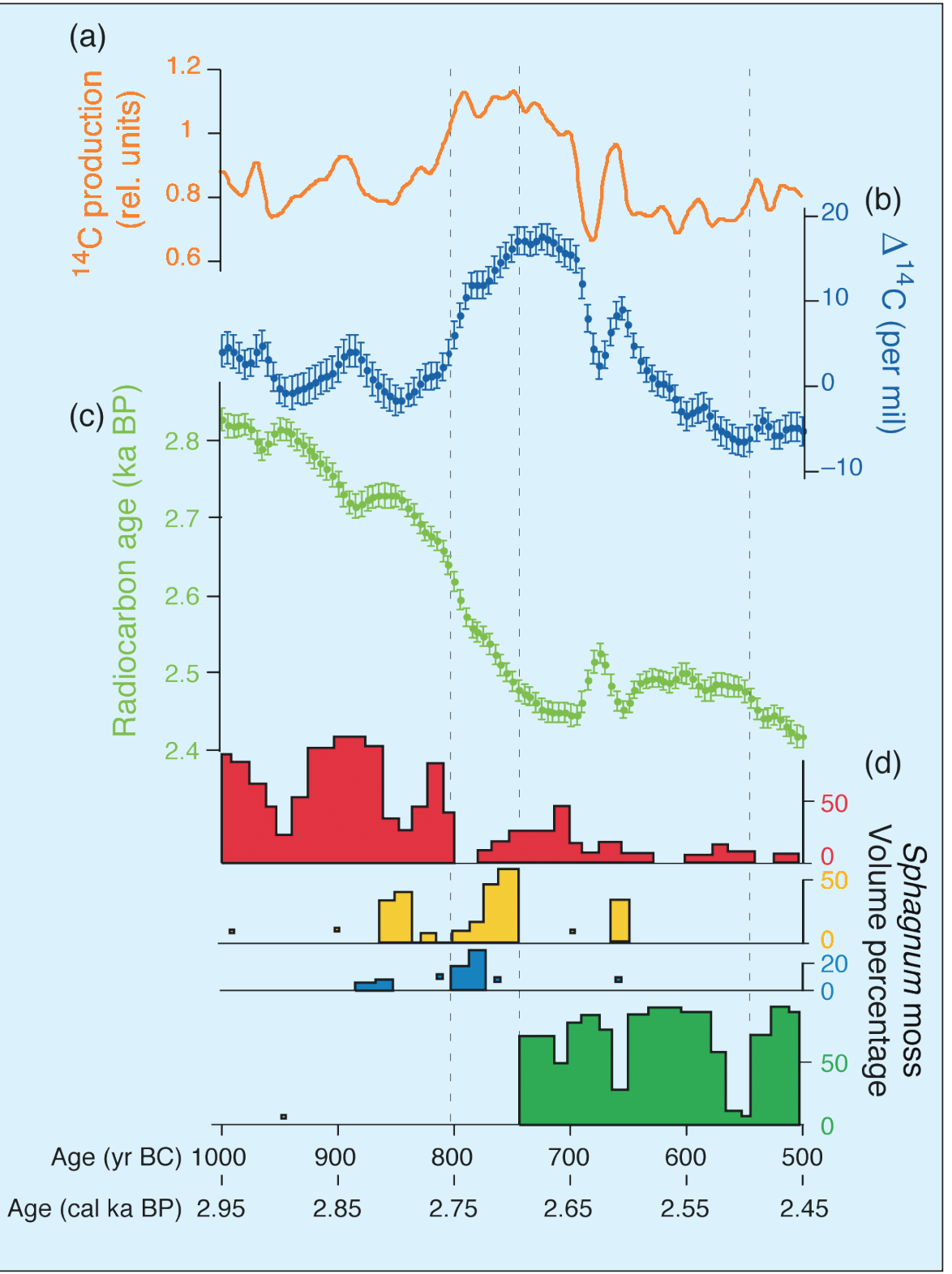

Figure 2: $\boldsymbol{a}$ ) Inferred changes in ${ }^{14} \mathrm{C}$ production (yellow). $\left.\boldsymbol{b}\right) \triangle^{14} \mathrm{C}$ is the deviation of the atmospheric ${ }^{14} \mathrm{C} /{ }^{12} \mathrm{C}$ ratio from a standard value in per mil (Stuiver and Pollach, 1977). The interval between ca. 2.8 and $2.7 \mathrm{cal}$ ka BP represents the phase of extreme climate at the start of the Subatlantic period: the rise of $\triangle^{14} \mathrm{C}$ and the ${ }^{14} \mathrm{C}$ production curve are related to a temporary decline of solar activity; $\boldsymbol{c}$ ) The ${ }^{14} \mathrm{C}$ calibration curve (Reimer et al., 2004). $\boldsymbol{d}$ ) Changes in composition of Sphagnum moss species during the Subboreal-Subatlantic transition (Engbertsdijksveen, eastern Netherlands; after van Geel et al., 1996; Beer and van Geel, 2008) reflect a sharp transition from relatively warm-dry (S. section acutifolia (red)) to cool wet conditions (S. cuspidatum (blue), S. papillosum (yellow), S. imbricatum (green)). Figure modified from Beer and van Geel, 2008).

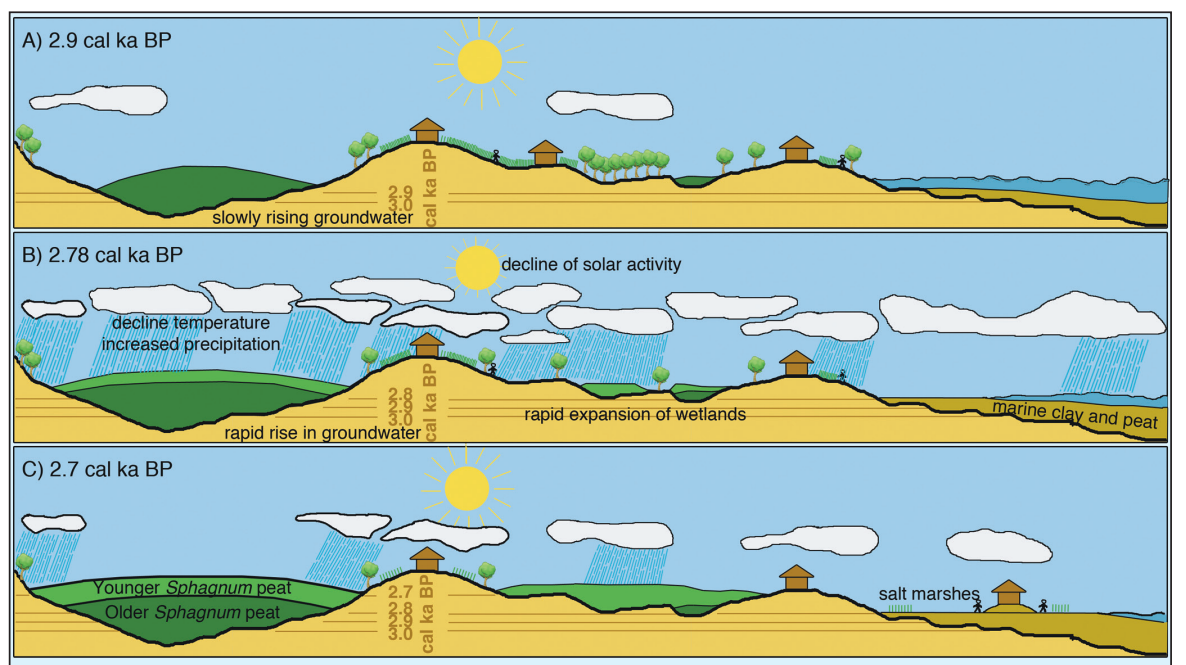

Figure 3: Landscape effects of solar forcing of climate change just before, during and directly after the Subboreal Subatlantic transition in the northern Netherlands (modified from van Geel et al., 1998; Beer and van Geel, 2008). ma), is presented in Mauquoy et al. (2002a, b) and Mauquoy et al. (2008). Replicate cores were investigated from one site in Denmark (2 peat profiles from Lille Vildmose) and northern England (3 replicate cores from Walton Moss). Paleohydrological reconstructions based on plant macrofossil and testate amoebae at a second site in northern England also record Little Ice Age climatic cooling (Mauquoy et al., 2008).

These increases in peatland surface wetness also coincide with some changes in solar activity; they are coeval with increases in the production of ${ }^{14} \mathrm{C}$. All of the peat profiles possess precise ${ }^{14} \mathrm{C}$ wigglematch dated chronologies, and the chronology from Lille Vildmose offers a very high-resolution record of climate change spanning the last $1.5 \mathrm{ka}$, with peat accumulation rates as high as $2-3 \mathrm{yr} \mathrm{cm}^{-1}$. The study by Mauquoy et al. (2008; see also Chambers et al., this issue) indicates a short lag (10-40 years) between the start of the rise in ${ }^{14} \mathrm{C}$ production and the hydrological response of the peat bog. We do not know the reason for this. Analyses of further peat profiles are needed to replicate this finding. Additional evidence for solar forcing of climate change comes from studies of marine sediments, stalagmites, ice cores and lake sediment, showing the sensitivity of the climate system to relatively small changes in solar activity (Bond et al., 2001; Neff et al., 2001; Magny, 2004, 2007).

\section{References}

Beer, J. and van Geel, B., 2008: Holocene climate change and the evidence for solar and other forcings. In: R.W. Battarbee and H.A. Binney (Eds), Natural Climate Variability and Global Warming: Holocene Perspective, Wiley-Blackwell, 138-162.

Mauquoy, D., van Geel, B., Blaauw, M. and van der Plicht, J., 2002a: Evidence from northwest European bogs shows 'Little Ice Age' climatic changes driven by variations in solar activity, The Holocene, 12: 1-6.

Mauquoy, D., Yeloff, D, van Geel, B., Charman, D. and Blundell, A., 2008: Two decadally resolved records from north-west European peat bogs show rapid climate changes associated with solar variability during the mid-late Holocene, Journal of Quaternary Science, 23: 745-763.

van Geel, B., Buurman, J. and Waterbolk, H.T., 1996: Archeological and paleoecological indications for an abrupt climate change in The Netherlands and evidence for climatological teleconnections around $2650 \mathrm{BP}$, Journal of Quaternary Science, 11: 451-460.

van Geel, B., et al., 2004: Climate change and the expansion of the Scythian culture after $850 \mathrm{BC}$, a hypothesis, Journal of Archaeological Science, 31: 1735-1742.

For full references please consult:

http://www.pages-igbp.org/products/newsletters/ref2010_1.htm 


\section{B. van Geel and D. Mauquoy}

Beer, J. and van Geel, B., 2008: Holocene climate change and the evidence for solar and other forcings. In: R.W. Battarbee and H.A. Binney (Eds), Natural Climate Variability and Global Warming: a Holocene Perspective, Wiley-Blackwell, 138-162.

Blaauw, M., Heuvelink, G.B.M., Mauquoy, D., van der Plicht, J. and van Geel, B., 2003: A numerical approach to $14 \mathrm{C}$ wiggle-match dating of organic deposits: best fits and confidence intervals, Quaternary Science Reviews, 22: 1485-1500.

Bond, G., Kromer, B., Beer, J., Muscheler, R., Evans, M.N., Showers, W., Hoffmann, S., LottiBond, R., Hajdas, I. and Bonani, G., 2001: Persistent solar influence on North Atlantic climate during the Holocene, Science, 294: 2130-2136.

Chambers, F., Daniell, J.R.G. and ACCROTELM Members, 2010: Peatland archives of lateHolocene climate change in northern Europe, PAGES news, 18(1).

Kilian, M.R., van der Plicht, J. and van Geel, B., 1995: Dating raised bogs: new aspects of AMS ${ }^{14} \mathrm{C}$ wiggle matching, a reservoir effect and climatic change, Quaternary Science Reviews, 14: 959-966.

Magny, M., 2004: Holocene climate variability as reflected by mid-European lake level fluctuations, and its probable impact on prehistoric human settlements, Quaternary International, 113: 65-79.

Magny, M., 2007: Lake level studies - West-Central Europe. In: Encyclopedia of Quaternary Studies, Vol. 2, pp. 1389-1399. Elsevier, Amsterdam.

Mauquoy, D., van Geel, B., Blaauw, M. and van der Plicht, J., 2002a: Evidence from northwest European bogs shows 'Little Ice Age' climatic changes driven by variations in solar activity, The Holocene, 12: 1-6.

Mauquoy, D., Engelkes, T., Groot, M.H.M., Markesteijn, F., Oudejans, M.G., van der Plicht, J. and van Geel, B., 2002b: High-resolution records of late-Holocene climate change and carbon accumulation in two north-west European ombrotrophic peat bogs, Palaeogeography, Palaeoclimatology, Palaeoecology, 186: 275-310.

Mauquoy, D., Yeloff, D, van Geel, B., Charman, D. and Blundell, A., 2008: Two decadally resolved records from north-west European peat bogs show rapid climate changes associated with solar variability during the mid-late Holocene, Journal of Quaternary Science, 23: 745-763.

Neff, U., Burns, S., Mangini, A., Mudelsee, M., Fleitmann, D. and Matter, A., 2001: Strong coherence between solar variability and the monsoon in Oman between 9 and $6 \mathrm{kyr}$ ago, Nature, 411: 290-293.

Reimer, P.J., et al., 2004: INTCAL04 terrestrial radiocarbon age calibration, 0-26 cal kyr BP, Radiocarbon, 46: 1029-1058.

Speranza, A., van Geel, B. and van der Plicht, J., 2002: Evidence for solar forcing of climate change at ca. $850 \mathrm{cal} \mathrm{BC}$ from a Czech peat sequence, Global and Planetary Change, 35: 51-65.

Stuiver, M. and Pollach, H.A., 1977: Discussions of reporting ${ }^{14} \mathrm{C}$ data. Radiocarbon, 19: 355363.

van der Plicht, J., van Geel, B., Bohncke, S.J.P., Bos, J.A.A., Blaauw, M., Speranza, A.O.M., Muscheler, R. and Björck, S., 2004: Early Holocene solar forcing of climate change in Europe, Journal of Quaternary Science, 19: 263-269.

van Geel, B. and Mook, W.G., 1989: High-resolution ${ }^{14} \mathrm{C}$ dating of organic deposits using natural atmospheric ${ }^{14} \mathrm{C}$ variations, Radiocarbon, 31: 151-156.

van Geel, B., Buurman, J. and Waterbolk, H.T., 1996: Archeological and paleoecological indications for an abrupt climate change in The Netherlands and evidence for climatological teleconnections around 2650 BP, Journal of Quaternary Science, 11: 451460.

van Geel, B., van der Plicht, J., Kilian, M.R., Klaver, E.R., Kouwenberg, J.H.M., Renssen, H., Reynaud-Farrera I. and Waterbolk, H.T., 1998: The sharp rise of $\Delta^{14} \mathrm{C}$ ca. $800 \mathrm{cal} \mathrm{BC:}$ possible causes, related climatic teleconnections and the impact on human environments, Radiocarbon, 40: 535-550. 
van Geel, B., et al., 2004: Climate change and the expansion of the Scythian culture after 850 BC, a hypothesis, Journal of Archaeological Science, 31: 1735-1742. 